\title{
Pseudomonas pickettii, a New Species of Clinical Origin Related to Pseudomonas solanacearum
}

\author{
ERICKA RALSTON, N. J. PALLERONI, and M. DOUDOROFF
}

Department of Bacteriology and Immunology, University of California, Berkeley, California 94720

\begin{abstract}
Twenty strains of Pseudomonas isolated from clinical specimens were found to constitute a homogeneous group which we recognize as a species and name Pseudomonas pickettii. On the basis of deoxyribonucleic acid hybridization data, this species appears to be most closely related to the phytopathogenic species $P$. solanacearum. The type strain of $P$. pickettii is K-288 (ATCC 27511).
\end{abstract}

Thirty-five bacterial strains isolated from hospital specimens were received by us from $\mathbf{M}$. J. Pickett, with the tentative identification of Pseudomonas pseudoalcaligenes type 2. When tested by our methods $(4,7) 19$ of these strains were found to constitute a phenotypically homogeneous group which differs in over 40 characters from both $P$. pseudoalcaligenes and $P$. alcaligenes as described by us (7). Another strain, also received from M. J. Pickett as an "unclassified denitrifier," could also be assigned to this homogeneous group. We further compared the phenotypic properties of this group of strains with those of other well-characterized Pseudomonas species and performed a limited number of deoxyribonucleic acid (DNA)-DNA hybridization experiments to determine whether it may represent a new species.

\section{MATERIALS AND METHODS}

Bacterial strains. All the bacterial strains used by us are designated by the numbers under which they were received from M. J. Pickett, Department of Bacteriology, University of California, Los Angeles. All, except strain K-300, which was sent as an "unclassified denitrifier," were tentatively identified by Pickett as $P$. pseudoalcaligenes type 2 . The original source of strain K-214 was a "Sephadex eluate" from Olive View Hospital; the other 19 strains were isolated in the Clinical Laboratories of the University of California, Los Angeles. Ten strains (K-288, K-298, K-472, $\mathrm{K}-507, \mathrm{~K}-529$, K-550, K-560, K-572, K-615, and K-633) were isolated from patients who had undergone tracheotomies. Two strains (K-618 and K-619) were isolated from the blood of a patient. Strain K-599 was isolated from hospital equipment. The original sources of six strains $(\mathrm{K}-48, \mathrm{~K}-300, \mathrm{~K}-421$, $\mathrm{K}-444, \mathrm{~K}-487$, and $\mathrm{K}-551$ ) are not recorded. Strains of all other Pseudomonas species reported here are designated as in our previous publications $(1,2,3,5$, 7).

Methods. The methods used for the phenotypic characterization of the strains have been described by Stanier et al. (7). The phenotypic similarity coefficients (6) for positive characters only $\left(S_{J}\right)$ and for positive and negative matches $\left(\mathbf{S}_{\mathbf{S M}}\right)$ were calculated by using 169 morphological, nutritional, and biochemical characters that we had found useful for differentiating among Pseudomonas species. DNADNA hybridizations were performed by the competition and direct binding techniques as described by Ballard et al. (1) and by Palleroni and Doudoroff (3).

\section{RESULTS AND DISCUSSION}

The twenty strains studied by us formed a phenotypically homogeneous group which could be distinguished from all other Pseudomonas species that we had studied or that we could recognize from the literature. Because strains of this group appear to be of somewhat common occurrence in clinical specimens, and can apparently be misidentified as members of other species (e.g., P. pseudoalcaligenes), we propose to create a new species which we name after M. J. Pickett, P. pickettii. The phenotypic properties of the type strain and of other members of the group are presented in the formal description and in Table 1.

DNA-DNA hybridization experiments showed a high degree of homology among three representative strains of $P$. pickettii and a relatively low degree of homology with strains of other selected species (see Table 2). On the basis of DNA homology, it appears that the organisms of this group are most closely related to $P$. solanacearum and somewhat less closely related to members of the pseudomallei-cepacia group (4). 
TABLE 1. Nutritional properties of the strains of P. pickettii ${ }^{a}$

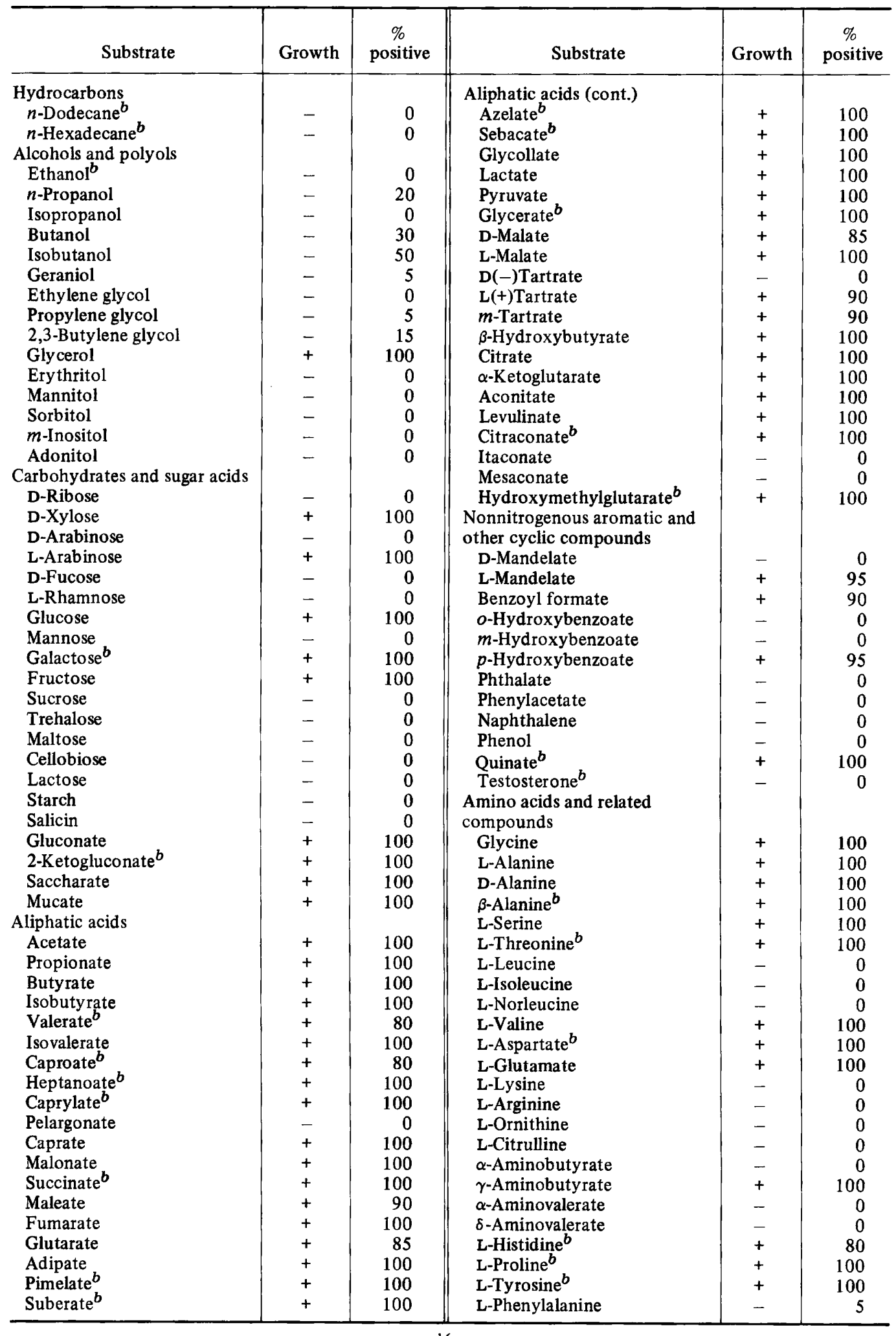


TABLE 1-Continued

\begin{tabular}{|c|c|c|c|c|c|}
\hline Substrate & Growth & $\begin{array}{c}\% \\
\text { positive }\end{array}$ & Substrate & Growth & $\begin{array}{c}\% \\
\text { positive }\end{array}$ \\
\hline $\begin{array}{l}\text { Amino acids and related } \\
\text { compounds (cont.) } \\
\text { L-Tryptophan } \\
\text { D-Tryptophan } \\
\text { Kynurenine }{ }^{b} \\
\text { Kynurenate } \\
\text { Anthranilate } \\
\text { Histamine } b \\
\text { Tryptamine } \\
\text { Miscellaneous compounds } \\
\text { Ethanolamine } \\
\text { Benzylamine } \\
\text { Putrescine }\end{array}$ & $\begin{array}{l}+ \\
- \\
+ \\
+ \\
- \\
- \\
- \\
- \\
- \\
-\end{array}$ & $\begin{array}{r}100 \\
55 \\
80 \\
100 \\
0 \\
20 \\
0 \\
\\
0 \\
0 \\
0\end{array}$ & $\begin{array}{l}\text { Miscellaneous compounds } \\
\text { Spermine } \\
\text { Butylamine } \\
\alpha \text {-Amylamine } \\
\text { Betaine } \\
\text { Sarcosine } \\
\text { Creatine } \\
\text { Hippurate } \\
\text { Pantothenate } \\
\text { Acetamide } \\
\text { Nicotinate } \\
\text { Trigonelline }\end{array}$ & $\begin{array}{l}- \\
- \\
- \\
- \\
- \\
- \\
+ \\
- \\
- \\
- \\
-\end{array}$ & $\begin{array}{r}0 \\
0 \\
0 \\
0 \\
0 \\
0 \\
100 \\
0 \\
0 \\
0 \\
5\end{array}$ \\
\hline
\end{tabular}

${ }^{a}$ For each substrate tested as a sole carbon source, growth or no growth of the type strain is indicated by + or -. Numbers refer to percent of all strains tested that are positive for the character. Strain numbers of positive strains for each substrate used by a fraction of the strains are the following: n-propanol, K-214, K-472, K-615, $\mathrm{K}-618$; butanol, $\mathrm{K}-48, \mathrm{~K}-214$, $\mathrm{K}-615, \mathrm{~K}-618, \mathrm{~K}-619$, K-633; isobutanol, $\mathrm{K}-214, \mathrm{~K}-298, \mathrm{~K}-421, \mathrm{~K}-472$, $\mathrm{K}-487$, K-507, K-529, K-550, K-615, K-618; geraniol, K-214; 2,3-butylene glycol, K-550, K-615, K-618; valerate, all except K-300; caproate, all except K-300; maleate, all except K-615, K-618; glutarate, all except K-300, K-615, $\mathrm{K}-618$; D-malate, all except K-300, K-615, K-618; L(+)tartrate, all except K-615, K-618, $m$-tartrate, all except K-615, K-618; L-mandelate, all except K-214; benzoyl formate, all except K-214, K-300; p-hydroxybenzoate, all except K-214; L-histidine, all except K-300; L-phenylalanine, K-300; D-tryptophan, K-48, K-214, K-472, K-507, $\mathrm{K}-529$, K-551, K-560, K-615, K-618, K-619, K-633; kynurenine, all except K-633; histamine, K-300; trigonelline, $\mathrm{K}-550$.

b Only 5 of the 20 strains were tested: K-288, K-300, K-421, K-550, K-633.

TABLE 2. DNA competition experiments using $P$. pickettii strain $K \cdot 288$ as reference, compared with similarity $\left(S_{J}\right)$ and matching $\left(S_{S M}\right)$ coefficients

\begin{tabular}{|c|c|c|c|c|c|}
\hline DNA from & $\begin{array}{c}\text { Mol \% } \\
\text { guanine plus } \\
\text { cytosine }\end{array}$ & $\begin{array}{c}\text { Competition } \\
\text { at } 71 \mathrm{C} \\
(\%)\end{array}$ & $\begin{array}{c}\text { Direct } \\
\text { binding } \\
(\%)\end{array}$ & $\mathbf{S}_{\mathbf{J}}$ & $\mathrm{S}_{\mathbf{S M}}$ \\
\hline 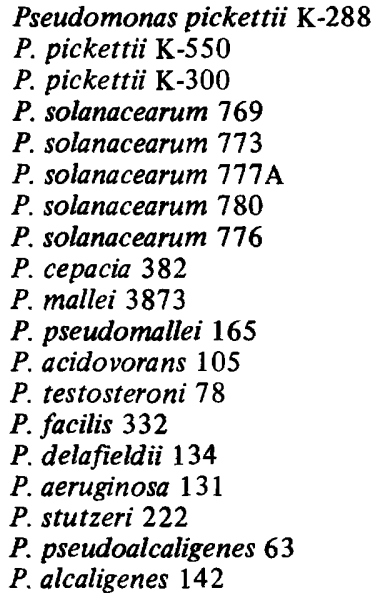 & $\begin{array}{l}64 \\
64 \\
64 \\
66 \\
66 \\
66 \\
69 \\
66 \\
67 \\
68 \\
69^{b} \\
66 \\
61 \\
64 \\
65 \\
68 \\
65 \\
62 \\
66\end{array}$ & $\begin{array}{r}100 " \\
100 \\
90 \\
56 \\
37 \\
29 \\
29 \\
\text { ND } \\
26 \\
21 \\
11 \\
0 \\
10 \\
15 \\
0 \\
4 \\
8 \\
2 \\
2^{a}\end{array}$ & $\begin{array}{l}\text { "100" } \\
\text { ND } \\
\text { ND } \\
39 \\
\text { ND } \\
\text { ND } \\
\text { ND } \\
17^{a} \\
12 \\
\text { ND } \\
\text { ND } \\
\text { ND } \\
\text { ND } \\
\text { ND } \\
8 \\
5 \\
\text { ND } \\
3^{a} \\
\text { ND }\end{array}$ & $\begin{array}{c}100 " \\
97 \\
88 \\
46 \\
46 \\
54 \\
56 \\
55 \\
57 \\
46 \\
\text { ND } \\
56 \\
58 \\
39 \\
52 \\
51 \\
48 \\
34 \\
28\end{array}$ & $\begin{array}{r}\text { “100” } \\
99 \\
94 \\
74 \\
73 \\
75 \\
77 \\
76 \\
69 \\
63 \\
\text { ND } \\
74 \\
78 \\
67 \\
75 \\
68 \\
71 \\
64 \\
64\end{array}$ \\
\hline
\end{tabular}

${ }^{a}$ Values obtained in reciprocal hybridization experiments using $P$. solanacearum $776, P$. pseudoalcaligenes 63 , or $P$. alcaligenes 142 as reference.

$b$ DNA composition not determined for this strain but is very uniform for all other strains of the species tested.

c Not determined. 
In the following description, the characters of the species apply to the type strain except where otherwise indicated. The nutritional properties of the type strain and of other strains of $P$. pickettii are indicated in Table 1. The constellations of phenotypic characters that distinguish this species from all other Pseudomonas species that have been thoroughly characterized by our methods are indicated in the footnote to the formal description.

Pseudomonas pickettii sp. nov. pick. et' ti.i. Pickett patronymic; M. L. gen. noun pickettii of Pickett; named for M. J. Pickett.

Rods, approximately 0.5 to 0.6 by 1.5 to 3.0 $\mu \mathrm{m}$, occurring singly, in pairs, and more rarely in short chains. Accumulate poly- $\beta$-hydroxybutyrate granules as carbon reserve ${ }^{2}$. Motile by means of a single polar flagellum ${ }^{b}$ (cells with two flagella are also observed, although very infrequently). The wavelength of the flagella is approximately $1.7 \mu \mathrm{m}$ (Fig. 1). Gram negative.
Colonies are not pigmented ${ }^{\mathbf{c}}$, and soluble pigments are not produced ${ }^{\mathrm{a}}$.

Nitrate reduced to nitrogen gas ${ }^{e}$. Arginine dihydrolase reaction, negative ${ }^{f}$. Oxidase reaction, positiveg. No hydrolysis of gelatin ${ }^{\mathrm{h}}$, starch $^{i}$, or extracellular poly- $\beta$-hydroxybutyrate $^{j}$. Polyethylene sorbitan monooleate (Tween 80 ) is hydrolyzed. Egg yolk reaction, negative.

Organic growth factors not requiredk. At least 66 different organic compounds can be used as sole carbon sources by the type strain and at least nine other compounds by other strains (Table 1). These include several monosaccharides and sugar acids and a large number of mono-, di-, and tricarboxylic acids and amino acids. Not used as carbon sources are disaccharides, most polyols, and amines. Substrates of diagnostic importance in distinguishing this species from all other species that have been well characterized include glucose ${ }^{\mathbf{l}}$, galactose ${ }^{\mathbf{m}}$,

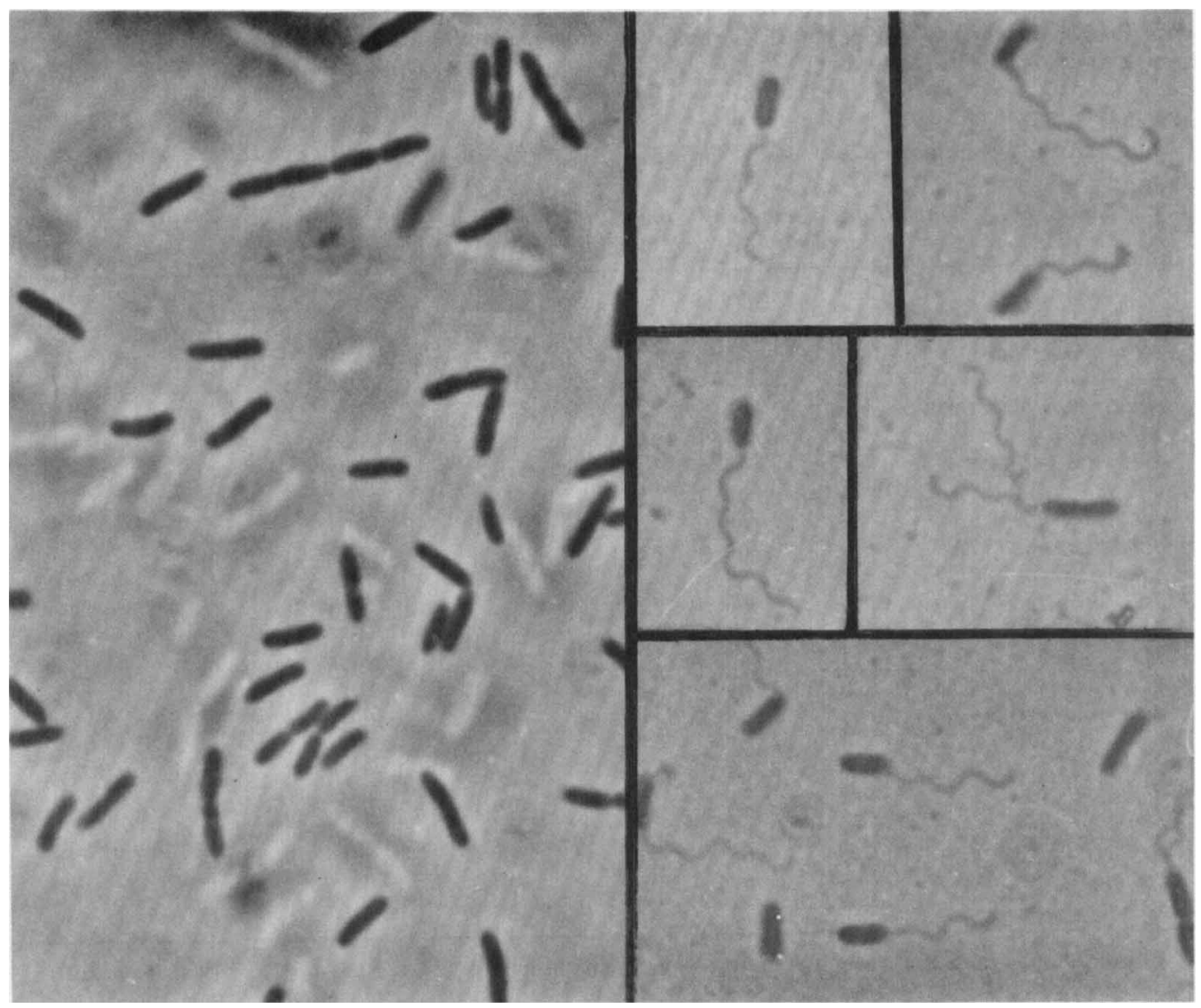

FIG. 1. Pseudomonas pickettii, strain $K$-288. Left, phase-contrast photograph of exponentially grown cells. Right, Leifson flagella stain. Magnification, $\times 3,000$. 
$\mathbf{L}_{\text {-arabinose }} \mathbf{n}$, malonate ${ }^{\circ}$, suberate $^{\mathbf{p}}$, and L-tryptophan $\mathbf{q}$, which are utilized by all strains, as well as $\mathrm{D}$-arabinose $\mathrm{r}^{\mathbf{r}}$ maltose ${ }^{\mathrm{s}}$, sucrose ${ }^{\mathrm{t}}$, ethanol $^{\mathbf{u}}$, mannitolv, and ethylene glycol $^{\mathbf{w}}$, which are not utilized by any strain. Almost all strains, including the type strain, use mandelate and $p$-hydroxybenzoate. The latter compound is metabolized via the ortho cleavage of protocatechuate. All strains use ammonium salts or nitrate as nitrogen sources.

Does not grow autotrophically with the oxidation of $\mathrm{H}_{2}$ as a source of energy $\mathbf{x}$.

Obligately aerobic except in media with nitrate as an electron acceptor. Optimal temperature, approximately $35 \mathrm{C}$. Growth at $41 \mathrm{C}^{\mathrm{y}}$ but not at $4 \mathrm{C}$.

The guanine plus cytosine content of the DNA is approximately $64 \mathrm{~mol} \%$ (by buoyant density). DNA-DNA hybridization experiments indicate a relatively close relationship of this species to $P$. solanacearum, a more distant relationship to $P$. cepacia and $P$. mallei, and virtually none with $P$. pseudoalcaligenes and other Pseudomonas species tested (Table 2).

Type strain: K-288. Deposited in the American Type Culture Collection (ATCC), Rockville, Md., under the number 27511.

a-y Positive and negative characters useful for differentiating $P$. pickettii from some other Pseudomonas species as follows: $a, d, f, h, u, v ~ P$. aeruginosa; $\mathrm{a}, \mathrm{b}, \mathrm{d}, \mathrm{f}, \mathrm{h}, \mathrm{y} P$. fluorescens; $\mathrm{a}, \mathrm{b}, \mathrm{d}, \mathrm{e}, \mathrm{f}, \mathrm{y}$ $P$. putida; a,b,d,g,n,y $P$. syringae group; a,b,d, $\mathrm{e}, \mathrm{q}, \mathrm{t}, \mathrm{y} P$. cichorii; $\mathrm{e}, \mathrm{f}, \mathrm{l}, \mathrm{m}, \mathrm{n}, \mathrm{o}, \mathrm{p} P$. alcaligenes; $\mathrm{e}, \mathbf{l}, \mathrm{m}, \mathrm{n}, \mathbf{o}, \mathbf{p} P$. pseudoalcaligenes; $\quad \mathbf{a}, \mathrm{c}, \mathrm{f}, \mathrm{m}, \mathrm{u} P$. mendocina; a,i,n,s,w $P$. stutzeri; $\quad \mathbf{b}, \mathbf{e}, \mathbf{l}, \mathbf{m}, \mathbf{n}, \mathbf{y} P$. acidovorans; b,e,1,m,n,o,y $P$. testosteroni; b,e,r, t,v $P$. cepacia; $\quad \mathbf{b}, \mathbf{e}, \mathbf{h}, \mathbf{r}, \mathrm{t}, \mathrm{u}, \mathbf{v} P$. marginata;

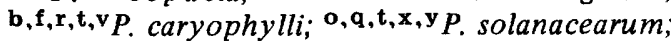
$\mathrm{b}, \mathrm{f}, \mathrm{h}, \mathbf{i}, \mathbf{j}, \mathrm{r}, \mathrm{s}, \mathrm{t}, \mathbf{v} P$. pseudomallei; $\mathrm{b}, \mathbf{f}, \mathbf{h}, \mathbf{j}, \mathrm{t}, \mathrm{v} P$. mallei; $\mathbf{e}, \mathbf{k}, \mathbf{l}, \mathrm{m}, \mathrm{n}, \mathrm{q} P$. diminuta; $\mathrm{c}, \mathrm{e}, \mathrm{k}, \mathrm{n}, \mathrm{q}, \mathrm{y} P$. vesicularis; $\mathbf{a}, \mathbf{b}, \mathbf{e}, \mathbf{g}, \mathbf{h}, \mathbf{k}, \mathbf{s , t}, \mathbf{y} P$. maltophilia; $\mathbf{e , j , 1 , m , n , ~}$

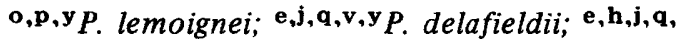
$\mathbf{x}, \mathbf{y} P$. facilis; $\mathbf{e , i , o , q , t , s , x , y} P$. saccharophila; $e$, $\mathrm{m}, \mathrm{n}, \mathrm{o}, \mathrm{u}, \mathrm{x}, \mathrm{y} P$. ruhlandii; $\mathbf{c}, \mathbf{e}, \mathrm{o}, \mathrm{s}, \mathrm{t}, \mathbf{x},{ }^{\mathrm{y}} P$. flava; c,e, $\mathrm{m}, \mathrm{n}, \mathrm{o}, \mathrm{u}, \mathrm{x}, \mathrm{y} P$. palleronii.

\section{ACKNOWLEDGMENTS}

We thank M. Rogul for providing us with DNA from $P$. mallei and $P$. pseudomallei and to Manley Mandel for determining the DNA composition of $P$. pickettii.

This work was supported by Public Health Service grant AI-1808 from the National Institute Allergy and Infectious Diseases.

Address requests for reprints to: Dr. N. J. Palleroni, Department of Bacteriology and Immunology, University of California, Berkeley, Calif. 94720.

\section{LITERATURE CITED}

1. Ballard, R. W., N. J. Palleroni, M. Doudoroff, R. Y. Stanier, and M. Mandel. 1970. Taxonomy of the aerobic pseudomonads: Pseudomonas cepacia, $P$. marginata, $P$. alliicola and $P$. caryophylli. J. Gen. Microbiol. 60: 199-214.

2. Davis, D. H., R. Y. Stanier, M. Doudoroff, and M. Mandel. 1970. Taxonomic studies on some gram negative polarly flagellated "hydrogen bacteria" and related species. Arch. Mikrobiol. 70:1-13.

3. Palleroni, N. J., and M. Doudoroff. 1971. Phenotypic characterization and deoxyribonucleic acid homologies of Pseudomonas solanacearum. J. Bacteriol. 107:690-696.

4. Palleroni, N. J., and M. Doudoroff. 1972. Some properties and taxonomic subdivisions of the genus Pseudomonas. Annu. Rev. Phytopathol. 10:73-100.

5. Ralston, E., N. J. Palleroni, and M. Doudoroff. 1972. Deoxyribonucleic acid homologies of some so-called Hydrogenomonas species. J. Bacteriol. 109:465-466.

6. Sokal, R. R., and P. H. A. Sneath. 1963. Principles of numerical taxonomy. W. H. Freeman and Co., San Francisco.

7. Stanier, R. Y., N. J. Palleroni, and M. Doudoroff. 1966. The aerobic pseudomonads: a taxonomic study. J. Gen. Microbiol. 43:159-271. 